\title{
Morální teologie pro neteology
}

L I B O R O V E ČK A

Studium teologie, a o morální teologii či teologické etice to platí tím spíše, podobně jako studium filosofe má nejen informativní, ale také formativní stránku, tj. nejde v něm jen o získání znalostí, osvojení způsobu myšlení, argumentování apod., nýbrž zároveň o sebereflexi a reflexi životní zkušenosti vlastní i ostatních lidí a z toho vyvoditelné a vyvozované důsledky. Je zřejmé, že formativní stránka se týká osobnosti studenta a že ji nelze dost dobře hodnotit nějakou atestací, přesto představuje nezanedbatelnou součást studia.

Studium teologické etiky tedy staví před studenty dvojí cíl. Zaprvé nabýt patřičných vědomostí o mravnosti, resp. o morální teologii. Pokud se tak děje $v$ rámci školního studia, tyto vědomosti lze zkoušet a hodnotit. A zadruhé mají studenti tímto způsobem provést jistou „rekonstrukci svědomí“ - sebereflexí ověřit, zda postoje jejich svědomí obstojí před racionální kritikou, a pokud ne, tak je korigovat. Toto je sice vlastní cíl a smysl studia morální teologie, avšak nelze ho hodnotit ani známkovat. Student, který tohoto cíle nedosáhl, může přesto dostat na základě svých vědomostí nejlepší hodnocení.

Katolická teologická fakulta Karlovy univerzity v Praze postupně buduje program kursů vyučovaných v anglickém jazyce. Patří k nim zejména letní škola základní morální teologie (Theological ethics), která běží se dvěma přestávkami od roku 2004. Kromě toho v roce 2011/12 poprvé běžel dvousemestrální kurs Fundamentals of theological ethics, který má obdobný program i rozsah. Tyto kursy se pořádají ve spolupráci s jesuitskou Loyola University v Baltimore, která všem studentům všech oborů předepisuje absolvování etického kursu; absolvovat jej mohou doma nebo v zahraničí. Kurs má pro baltimorskou univerzitu neutrální označení Ethics, ale fakticky se jedná o etiku teologickou. V konkrétní realizaci zprostředkuje základní témata z fundamentální etiky na základě mravní dilemat, navazujících na zkušenost studentů.

Ve srovnání se studiem etiky a morální teologie v denním studiu Katolické teologické fakulty mají tyto kursy několik zvláštních rysů.

První z nich je omezení v čase - letní kurs má celkem 45 vyučovacích hodin včetně závěrečné zkoušky. Protože se musí vejít do čtyř týdnů, není možno studentům zadávat mnoho samostatné práce. 
Druhé omezení se týká předchozí praktické a studijní zkušenosti studentů. Účastníci letní školy jsou převážně američtí studenti z Baltimore, většinou ve druhém roce univerzitního studia. Jsou poměrně dost závislí na svých rodičích - nejen ekonomicky, nebot rodiče za ně platí školné, nýbrž i myšlenkově. Většinou studují obory jako historie, sociologie, ekonomie..., avšak téměř nikdy to nejsou studenti teologie nebo filosofie. Životní zkušenost a prostředí, ze kterého pocházejí, se myšlenkově a kulturně liší od naší evropské, což snadno vede k vzájemným nedorozuměním. Možná i způsobem učení se liší od evropských studentů.

Třetí omezení se týká skutečnosti, že studenti mají různé postoje k náboženství. Na jednom konci spektra jsou ti, kdo málo vědí o křestanské víře, ale přesto jsou snad schopni chápat teologické argumenty, na druhém konci spektra jsou hluboce věřící studenti, kteří jen s obtížemi přijímají, že mravní požadavky potřebují racionální zdůvodnění a neplynou prostě z víry.

Čtvrté omezení se týká motivace studentů ke studiu v kursu. Ta může být dost rozdílná, zpravidla není př́liš silná. Silnější motivaci než teologie představuje v Praze možnost setkání s neznámým prostředím a neznámou kulturou, což ovšem také patří k cílům kursu. Paralelně k etickému kursu studují studenti i kurs Úvod do české společnosti a kultury.

Stojíme tedy před otázkou, jak je možno za těchto okolností studentům zprostředkovat základní morální vědomosti, základy teologického myšlení o mravnosti, a zároveň jim umožnit formaci jejich životních postojů. Je to otázka, jakým způsobem mají být zkoušeni na závěr kursu a hodnoceni.

Letní kurs se nemůže a nesmí soustřed'ovat na sumu znalostí, které by studenti měli získat a ze kterých by měli být zkoušeni, nebot' na to není dost času. Studenti jsou pochopitelně v pokušení brát teologickou etiku jako jiný školní předmět, což by pro ně bylo snazší, avšak kurs v daném čase takovéto vědomosti nemůže zprostředkovat. Zároveň však platí, že studenti mají za cíl dosáhnout co nejlepšího závěrečného hodnocení.

Základním předpokladem úspěšného a smysluplného absolvování kursu je, že studenti se přestanou jen učit, co jim je za strany přednášejícího řečeno. Měli by studovat proto, že je předmět zajímá a že ho potřebují pro svůj praktický život. I tento cíl je ovšem obtížně dosažitelný ve čtyřech týdnech. Očekávat změnu smýšlení za tak krátký 
čas by bylo nereálné. Navíc způsob hodnocení, na který jsou studenti zvyklí a který je zavedený na jejich univerzitě, se snaží o maximální objektivitu na základě přesných kritérií a počítá s devíti stupni známek. Známky jsou pro studenty důležité, nebot' ukazují jejich pokrok ve vědění, ale je obtížné vyjádřit jimi pokrok v mravních postojích a ve schopnosti teologické reflexe.

Přesto je žádoucí pokud možno zabránit studentům, aby brali teologickou etiku jen jako školní předmět, a přivést je k tomu, aby si položili základní teologickou otázku - co je zdůvodněním mravní povinnosti, co je základem mravnosti, proč jsme vázáni mravním řádem. Bez tohoto ujasnění by celý kurs do značné míry ztrácel smysl. Toto tázání je ovšem obtížné, i vzhledem k tomu, že se ve společnosti i v křestanské církvi odpověd' zpravidla považuje za tak samozřejmou, že se s důsledností nehledá a tím zpravidla není nalezena.

Toto tázání vyžaduje reflexi vlastního svědomí a reflexi důvodů, proč hodnotím mravnost určitého činu tak či onak. Jaký je např. důvod, proč považuji rozvod manželství za přípustný nebo za nepřípustný? Proč považuji homosexuální soužití za přípustné nebo za nepř́ípustné? Platí můj postoj jako obecné pravidlo, nebo platí jen v konkrétním př́padě? Vliv nereflektovaných zkušeností způsobuje např. to, že zpravidla v obecnosti studenti zastávají zásadu nerozlučnosti manželství, ale v konkrétním př́ípadě jednoznačně podporují právo na sebeurčení, na osobní štěstí a na rozvod a nový sňatek, jestliže se první manželství nevydařilo. Tím se ukazuje, že informace o konkrétních mravních normách se stává skutečnou informací, až když je konfrontována s reálnou životní zkušeností a reflektována v jejím světle.

Mezi zdroji mravního poznání stojí jistě na význačném místě odvolání na autoritu. Studenti žijící v církvi mají tendenci zdůvodňovat mravní požadavky církevní naukou. To však není dostatečnou a vyčerpávající mravní odpovědí, nebot' i autorita církve potřebuje zdůvodnění závaznosti svého slova. Pokud toto zdůvodnění neznám, nevím, zda má slovo autority pro mě závaznou platnost. Studenti se však zpravidla takto neptají a těmto otázkám nerozumí. V momentě, kdy by se studenti začali takto ptát a kdy by začali rozumět základní mravní otázce, hlavního cíle kursu by bylo dosaženo. Ale je nesnadné přivést je k takovému tázání ve čtyřech týdnech, zvláště když celé studijní prostředí je pro ně nové a neodpovídá tomu, na co byli zvyklí.

Potřeba konkrétního studijního materiálu vedla po několika letech k použití učebnice Neil Messer. SCM Studyguide to Christian Ethics 
(SCM Press 2006). Její autor, jak je to velmi časté, ovšem zmíněnou první etickou otázku neklade, začíná rovnou druhou etickou otázkou - co mám konkrétně dělat. To je na začátku 21. století obvyklý postup. Můžeme předpokládat, že autor odpověd' na první otázku zná, ale z metodických důvodů se jí v učebnici vyhýbá. Tuto znalost však nemůžeme předpokládat a studentů, a to dokonce ani u studentů žijících ve víře.

Aby se hodnocení opíralo o nějaká konkrétní a objektivní kritéria, promítá se do něj několik samostatně hodnotitelných položek: účast na hodinách, vypracování zadaných domácích prací, aktivita při diskusích... Přesto takto vypočítaná známka vyjadřuje spíše úspěšné absolvování kursu než úroveň vlastního morálního sebe-vědomí, nemůže vyjadřovat dosažené mravní povědomí, reflexi vlastní mravnosti. Hodnotit znalosti je nutné, nebot to vyžaduje řád studia, ale zároveň je to velký kámen úrazu celého kursu. Při závěrečném hodnocení se pak pochopitelně může stát, že se někteří studenti cítí zklamáni - očekávali dobrou známku, kterou nedostali, ačkoliv se jim přes všechna omezení podařilo novým způsobem objevit svět mravnosti a vstoupit do něj, v daném čase získali nové mravní povědomí. Hodnoceni jsou však na základě vnějších kritérií, která ve skutečnosti vůbec nemusí být tím nejdůležitějším, ale jsou jediná hodnotitelná.

Pedagogické východisko z této jakoby bezvýchodné situace je snad v tom, že vyučující bude trávit se studenty víc času, než jen předepsané vyučovací hodiny, bude s nimi komunikovat i mimo vyučování a stane se přes časové omezení součástí jejich životní zkušenosti. To umožňuje v teoretické výuce navazovat na poznatky ze života společnosti, z ekonomiky, politiky, kultury či náboženství české společnosti a v praxi se vracet k teoretickým poznatkưm. Kurs Fundamentals of theological ethics $\mathrm{v}$ tom dává přece jen větší možnosti, protože je rozložený v delším časovém úseku. Tím se víc propojuje teorie vyučování s praxí reálného života, i když hodnocení studentů musí zůstat na základě znalostí. Jak známo, nejdůležitější součástí kursu mohou být přestávky. 